\title{
PHYLOGENETIC ANALYSIS AND PREVALENCE OF HUMAN PAPILLOMAVIRUS (HPV) IN WOMEN WITH SEVERAL CERVICAL PATHOLOGIES
}

\author{
Gulcin Alp AVCI ${ }^{1,2}$, Gulendam BOZDAYI ${ }^{1}$, Cagatay TASKIRAN ${ }^{3}$, Secil OZKAN ${ }^{4}$, M. Anil ONAN ${ }^{3}$ \\ 1 Department of Medical Microbiology, Gazi University, Faculty of Medicine, Ankara, Turkey \\ 2 Department of Medical Microbiology, Health of High School, Corum, Turkey \\ 3 Department of Obstetrics and Gynecology, Gazi University, Faculty of Medicine, Ankara, Turkey \\ ${ }^{4}$ Department of Public Health, Gazi University, Faculty of Medicine, Ankara, Turkey
}

\begin{abstract}
SUMMARY
Objective: To determinate the prevalence of HPV types in patients with cervical cancers in our legion by Real time PCR and DNA sequence analysis and to make phylogenetic analysis was aimed in this study.

Material and methods: From January to October 2010, cervical swap samples of 77 patients directed to colposcopy were included in the study. HPV DNA and HPV type 16 were detected by Real Time polymerase chain reaction using the L1 region. Real Time PCR amplifications of MY09/11 products were done by GP5+/GP6+ primers and Cyanine-5 labeled HPV DNA and HPV type 16 specific probe. HPV types determinate by GP5+/GP6+. Phylogenetic analysis of sequences was calculated by Kimura's two parameters method. Statistically analyses were by using Pearson chi-square and odss ratio tests. Results: Forty seven samples (prevalence; 61\%) of total seventy seven cervical samples detected as HPV DNA positive. While HPV type 16; 52\%, HPV type 16+11; 4\%, HPV type 16+6; 1\% and non-typing HPV DNA 4\% of seventy seven samples determining, 39\% of samples observed as negative HPV. Participated in the study population, HPV DNA positive individuals are among 34-56 years. Most HPV DNA positivity rate of $80.0 \%$ was between the ages of 31 40. 52.2\% of HPV DNA positivity between the ages of 41-50 to fall, but again, 83.3\% between the ages of 51-60 to a second peak was determined that increased. 60.0\% of 20 ASC-H cases, 63.8\% of 36 ASC-US cases, $100 \% 9$ of HSIL cases and $25.0 \%$ of 12 LSIL cases were positive for HPV DNA.

Conclusion: The investigation of the distribution of HPV genotypes in women with cervical cancer and precancerous lesions in our region is important. Early diagnosis of HPV by using improved technological assays, play a key role to prevent the turn precancerous lesions into invasive cancers.
\end{abstract}

Key word: cancer of cervix, DNA sequence analysis, human papillomavirus, real time PCR, phylogenetic analysis

Journal of Turkish Society of Obstetrics and Gynecology, (J Turk Soc Obstet Gynecol), 2013; Vol: 10, Issue: 3, Pages: 151- 9

\section{ÇEŞITLİ SERVIKAL PATOLOJIYE SAHIP KADINLARDA HUMAN PAPILLOMAVIRUS (HPV) PREVALANSI VE FÍLOGENETIK ANALIZI}

ÖZET

Amaç: Bu çalışmada, çeşitli servikal patolojiye sahip hastalarda gerç ek zamanl polimeraz zincir reaksiyonu ve DNA dizi analizi HPV tiplerinin sıklı̆̆ının belirlenmesi ve filogenetik analizinin yapılması amaçlanmıştır.

Gereç ve yöntemler: Çalışmaya Ocak-Ekim 2010 tarihleri arasında kolposkopi önerilen 77 adet hastaya ait servikal

Address for Correspondence: Dr. Gülçin Alp Avc1. Hitit Üniversitesi Sağlık Yüksekokulu 19030 Çorum Phone: + 90 (506) 8560128

e-mail: alp.gulcin@yahoo.com

Received:12 March 2013, revised: 08 April 2013, accepted: 09 April 2013, online publication: 11 April 2013 
sürüntü örneği dahil edilmiştir. HPV DNA ve HPV tip 16 DNA's L1 bölgesi hedef alınarak gerçek zamanlı PCR ile belirlenmiştir. MY09/ 11 ürünlerinin amplifikasyonlarl gerçek zamanlı PCR ile GP5+/GP6+ primerleri, siyanin-5 işaretli HPV DNA ve HPV tip 16 DNA spesifik probları kullanılarak yapılmıştır. Dizi analizinde GP5+/GP6+ primerleri kullanılmıştır. Filogenetik analiz, Kimura'nın iki parametre yöntemi ile yapılmıştır. İstatistiksel analizinde ise Pearson'nun ki-kare ve odss ratio testlerinden yararlanılmıştır.

Sonuç: Toplam 77 servikal örneğin 47 (prevalans \%61)'si HPV DNA pozitif tespit edildi. yetmiş yedi örneğin \%52'si HPV 16; \%4'ü HPV tip 16 ve tip 11; \%1'i HPV tip 16 ve tip 6; ve \%4'ü tiplendirilemeyen HPV DNA belirlenirken, \%39'un da HPV'ye rastlanmadi. Insan papillomavirus pozitif bulunan bireylerin yaşları 34-56 arasinda olup, en fazla pozitiflik \%80,0 oranı ile 31-40 yaşları arasında belirlenmiştir. İnsan papillomavirus pozitifliğinin 41-50 yaşları arasında \%52,2'e düştügüu, ancak 51-60 yaşları arasında tekrar \%83,3'e yükselerek ikinci bir pik yaptığı görüldü. Ayrıca, 20 ASC-H'nin \%60,0'ında; 36 ASC-US' un \%63,8'inde; 9 HSIL'nin \%100'ünde ve 12 LSIL'nin \%25'inde HPV DNA pozitif olarak belirlendi.

Yorum: Hastanemizde serviks kanseri ve prekanseröz lezyonları olan kadınlarda HPV genotip dağılımının araştırılması önemlidir. Gelișen teknolojik yöntemler kullanılarak İnsan papillomavirusunun erken tanısı, prekanseröz lezyonların invaziv kanser haline dönüşmesini önlemek iç in anahtar rol oynamaktadır.

Anahtar sözcükler: DNA dizi analizi, filogenetik analiz, gerçek zamanlı PCR, insan papillomavirus, serviks kanseri Türk Jinekoloji ve Obstetrik Derneği Dergisi, (J Turk Soc Obstet Gynecol), 2013; Cilt: 10, Sayl: 3, Sayfa: 151- 9

\section{INTRODUCTION}

Human papillomavirus (HPV) is accepted as primary etiologic agent of cervical cancer worldwide. HPV can causes precancerous lesions outside of the genital area $^{(1)}$. The human papillomavirus is small and a double-stranded DNA virus that infects the epithelial cells of skin and mucosa(2). Today, approximately more than 200 types of HPV have been identified(3). The classification of these types; species origin and depends on the degree of homology between the viral genomes detected by DNA hybridization(4). HPV has been shown to be responsible not only the cervical cancer but also the skin and pharyngeal cancers, and other malignancies especially vulvar, vaginal, penile and anal cancers ${ }^{(5)}$. About $40 \mathrm{HPV}$ types infect the genital mucosal and are categorized according to their carcinogenic potential ${ }^{(6)}$.

Cervical cancer is the second most common type of cancer after breast cancer in the world. Over 500,000 new cases diagnosed each year and 275,000 patients die. $80 \%$ of the cases observed in developing countries ${ }^{(7)}$. According to the data of Ministry of Health of the Republic of Turkey; cervical cancer was detected 623 patients in 1996 and seventh among all women's cancers. This number was 708 patients in 2002, but tenth among all women's cancers declined. The cervical cancer was ninth with 763 patients in $2003^{(8)}$. Usually high grade lesions develop from low-grade lesions. But some cases directly is observed as high grade lesions. Genital HPV infection begins as low-grade lesion and able to continue to cancer ${ }^{(9)}$.

To determinate the prevalence of HPV types in patients with cervical cancers in our legion by Real time PCR and DNA sequence analysis and to make phylogenetic analysis was aimed in this study.

\section{MATERIAL AND METHODS}

Patients: Seventy seven patients who were referred to our outpatient clinic of Gazi University Medical Faculty Gynecology and Obstetrics Department between January-October 2010 with an indication of Colposcopy were included in this study. Approved by the local ethics committee (Ethics Committee of Gazi University, decision no. 23.02.2009/108) was taken for this study. Addition in the study, from patients participating during the sampling consent was obtained in terms of the study and to be carried out. The demographic information of patients of taken cervical swab samples in during the colposcopy such as age, number of children, number of pregnancies, smoking, oral contraceptives and intrauterine device (IUD) presented in Table I. Cytological examination of the samples was performed according to the modified Bethesda system $^{(10)}$. 
Table 1: The HPV positivity and use of smoking, oral contraceptives and intrauterine device (IUD) on patients of taken cervical swab samples.

\begin{tabular}{|c|c|c|c|c|}
\hline & HPV positivite (n:47) & Percent (\%) & HPV negative (n:30) & Percent (\%) \\
\hline \multicolumn{5}{|l|}{ Smoking } \\
\hline Yes $(n: 25)$ & 15 & $60.0 \%$ & 10 & $40.0 \%$ \\
\hline No (n:52) & 32 & $61.5 \%$ & 20 & $38.5 \%$ \\
\hline chi-square: 0.23 & \multicolumn{2}{|c|}{$p=0.6306$} & \multicolumn{2}{|c|}{ OR:0.79 (0.27-2.28) } \\
\hline \multicolumn{5}{|c|}{ Oral contraceptives } \\
\hline Yes (n:5) & 2 & $40.0 \%$ & 3 & $60.0 \%$ \\
\hline No (72) & 45 & $62.5 \%$ & 27 & $37.5 \%$ \\
\hline chi-square: 0.31 & \multicolumn{2}{|c|}{$\mathrm{p}=0.5882$} & \multicolumn{2}{|c|}{ OR:0.60 (0.06-4.78) } \\
\hline \multicolumn{5}{|c|}{ Intrauterine device } \\
\hline Yes (n:13) & 8 & $61.5 \%$ & 5 & $38.5 \%$ \\
\hline No (n:64) & 39 & $61.0 \%$ & 25 & $39.0 \%$ \\
\hline chi-square: 0.58 & \multicolumn{2}{|c|}{$p=0.4477$} & \multicolumn{2}{|c|}{ OR:1.60 (0.41-6.41) } \\
\hline
\end{tabular}

\section{Nucleic acid purification and real-time PCR application:}

Heliosis $(r)$ viral DNA extraction kit (Metis

Biotechnology, Turkey) was used in accordance with manufacturer's recommendations for viral nucleic acid purification in cervical swap samples. Then the purified nucleic acid stored in sterile distilled water and at $86^{\circ} \mathrm{C}$. Because the determination of HPV infection and HPV type 16 infection in cervical swap samples used a commercial system (Heliosis ${ }^{\mathrm{TM}}$ Human papillomavirus (HPV) LC PCR kit, Metis Biotechnology, Turkey) based on real time PCR method. The first amplification of products done by thermal cycler PTC-200 (MJ Research, USA). LightCycler ${ }^{\mathrm{TM}} 2.0$ (Roche Diagnostics, Germany) real time PCR was used for second amplification of products. Analysis results evaluated, peak between $69.5^{\circ} \mathrm{C}$ and $78.5^{\circ} \mathrm{C}$ for HPV type 16 , $80 \pm 2{ }^{\circ} \mathrm{C}$ peak for other HPV types (Figure 1). This study was used MY09 (5'CGTCCMARRGGAWACTGATC3'), MY11 (5'-GCMCAGGGWCATAAYAATGG-3'), GP5 (5'-TTTGTTACTGTGGTAGATAC-3') and GP6 (5'-GAAAAATAAACTGTAAATCA-3') primers with cyanine-5 marked HPV DNA and HPV type 16 DNA specific probes.

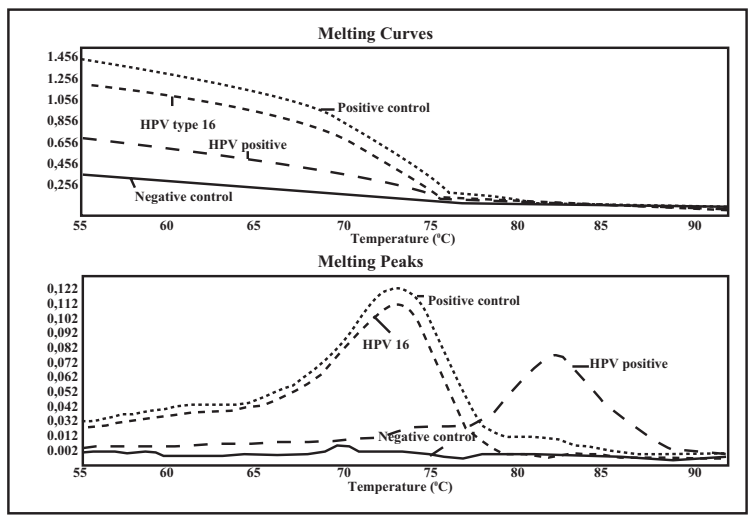

Figure 1: HPV type 16, other HPV types, positivite and negative controls.
Sequence analysis and Phylogenetic analysis: PCR products were gel imaging system (UVITEC Cambridge, England) is displayed, and sequence analysis identified the best samples. For the determining the sequences of HPV types, Squencing Big Dye Terminator Cycle (Applied Biosystems, USA) kit, GP5 + / GP6 + primers and the ABI Prism ${ }^{(\mathrm{r})}$ 3100XL Genetic Analyzer (Applied Biosystems, USA) were used. Genetic differences between sequences were calculated by Kimura's two-parameter method (K2P) ${ }^{(11)}$. Phylogenetic tree was created with MEGA 4.0.2 program after the calculation of their proximity with other sequences of sequences.

Statistics: Statistical evaluation, the data are presented with numbers and percentages. HPV 16 and HPV positivity between the groups compared the chi-square test. In addition, OR (95\% confidence interval) was calculated in some statements. Statistical significance was interpreted at the level of $\mathrm{p}=0.05$.

\section{RESULTS}

As a result of real-time PCR, HPV positivity were determined at forty seven (61\% prevalence) of 77 cervical samples. forty (52\%) HPV type 16 and 7 (9\%) mix type of HPV positive samples detected. However, HPV positivity were not determined at 30 (39\% prevalence) of 77 cervical samples (Figure 2). 


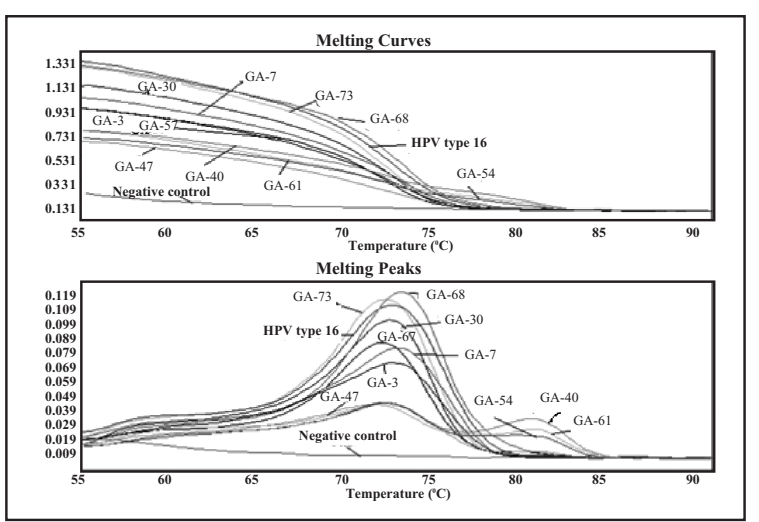

Figure 2: HPV type 16 and other HPV types.

The best samples were selected by electrophoresis for sequence analysis after PCR (Figure 3).

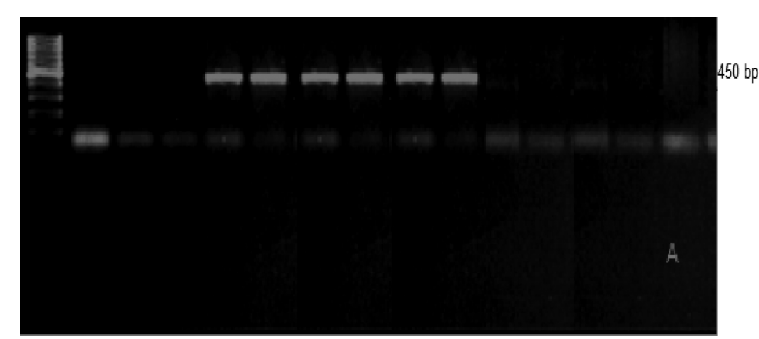

Figure 3: MY09/11 primers and 450 bp L1 gene.

The other types except for the HPV 16 were found by Real-time PCR. Five of these samples were sequenced. While the called as GA-22, GA-25, GA-69 and GA77 from these samples were observed, a cervical sample could not be determined. According to DNA sequence analysis, HPV 16 and HPV 11 types were detected in GA-22, GA-25, GA-77 HPV 16 and HPV 6 types was found in GA-69. Given in Figure 4, sequence of one from samples containing HPV type 11.

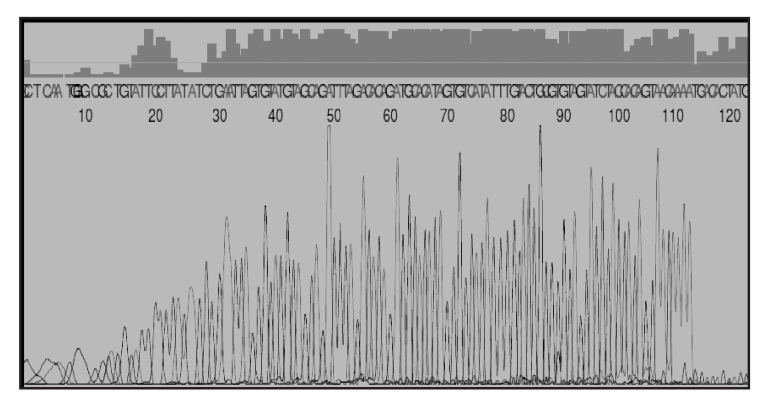

Figure 4: An example of a chromatogram obtained from genetic analysis apparatus (HPV type 11).
According to typing results, 52\% HPV type 16, 4\% HPV type 16-11, 1\% HPV type 16-6 and 1\% nontypable HPV of seventy seven samples were identified.

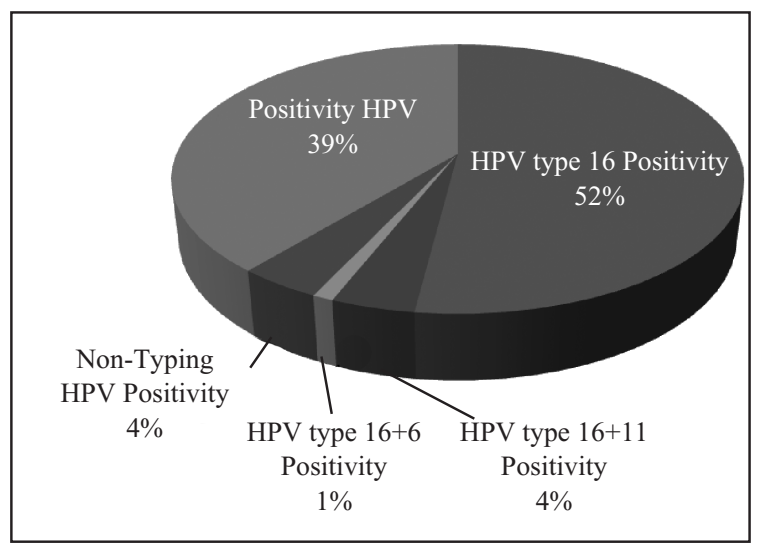

Figure 5: Real time PCR results in cervical samples.

The phylogenetic analysis of sequences was used from Kimura's two parameters (K2P) method. A result of analysis, the phylogenetic tree has been created MEGA 4.0.2 software (Figure 4). According to phylogenetic analysis, GA-22, GA-25 and GA-77 as HPV type 11; GA-69 as HPV types 6 were determined (Figure 6).

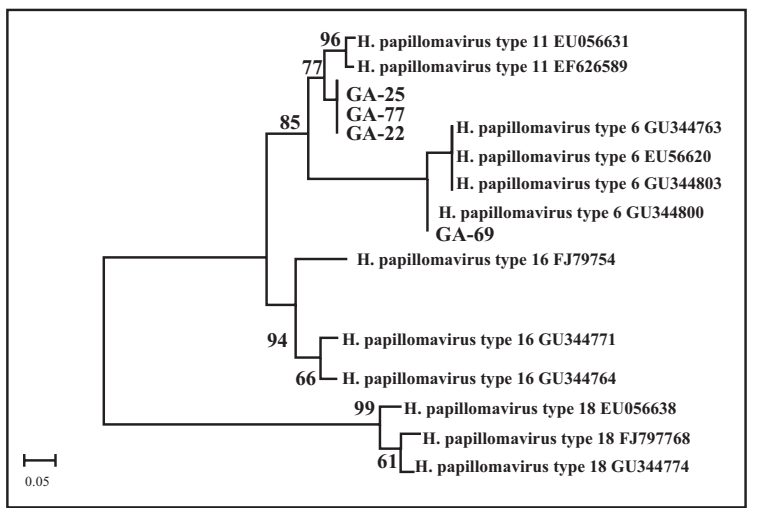

Figure 6: Phylogenetic tree of HPV types location. HPV type 11 called as GA-22, GA-25 and GA-77 and HPV types 6 called as GA69 type. The scale bar shows the distance between sequences.

According to the use of cigarettes and OKS of patients, statistically significant difference was not found in terms of HPV positivity ( $p>0.05$ ). However, Looking of HPV positivity according the use of RIA, RIA users were found statistically significant $(\mathrm{p}<0.05)$. This situation is interpreted 1.60 times greater on RIA users of HPV positivity (Table 1). 
Mean age of population participated in the study $45 \pm$ 24 and HPV-positive individuals aged between 34-56. All of the patients that positive for HPV DNA were over the age of 30. The maximum HPV DNA positivity determined between the ages of 31-40 with rate of $80.0 \%$. HPV positivity decreased $52.2 \%$ between the ages of 41-50. However, HPV positivity was detected $83.3 \%$ again risen to the second peak between the ages of 51 to 60 (Figure 7).

According to age groups, the difference was statistically significant for HPV positivity ( $p<0.05$, chi-square: $18.14, \mathrm{p}=0.0011)$. The difference was due to the lack of HPV-positive patients between the 21-30 and 61 and over age groups.

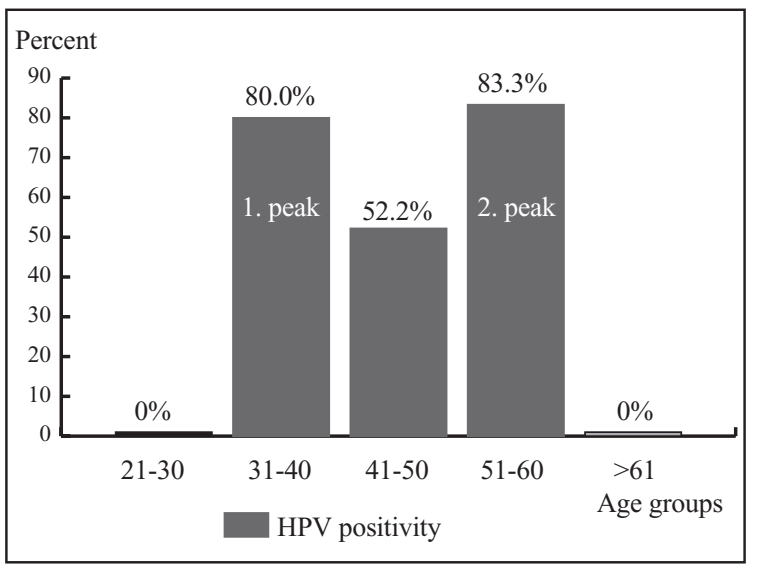

Figure 7: HPV positivity according to age groups.

HPV positivity is examined according to the number of children and pregnancy, it is increased together increased the number of both pregnancy and children. Especially, HPV positivity were obtained $71.4 \%$, for those between 2-4 the number of children (number of live births), and $68.0 \%$ for those between $2-4$ the number of pregnancy, $64.5 \%$ for those with more than 4 pregnancy $(p>0.05)$. By the numbers of children and pregnancy were found a statistically significant difference in terms of HPV positivity

In this study, pathology values of patients who had colposcopy are investigated and HPV DNA is found to be positive in $12(60.0 \%)$ of 20 ASC-H cases; 23 $(63.8 \%)$ of 36 ASC-US cases; 9 (100\%) of 9 HSIL cases and 3 (25.0\%) of 12 LSIL. According to pathology values, a statistically significant difference is found in terms of HPV positivity $(\mathrm{p}<0.05)$. This difference results from the fact that the whole group consisting of HSIL cases is HPV positive. In addition, pathological values of patients are evaluated with HPV types.
Accordingly; it is detected that among $12 \mathrm{HPV}$ positive ASC-H cases, 10 are HPV type 16, one is HPV type 16/type 11 and 1 is HPV DNA positive; among 23 HPV positive ASC-US cases, 23 are HPV type 16 positive; among 9 HPV positive HSIL cases, 7 are HPV type 16, one is HPV type 16/type 11 and one is HPV DNA positive; among $3 \mathrm{HPV}$ positive LSIL cases, one is HPV type 16/type 11, one is HPV type 16/type 6 and oneis HPV DNA positive (Figure 8).

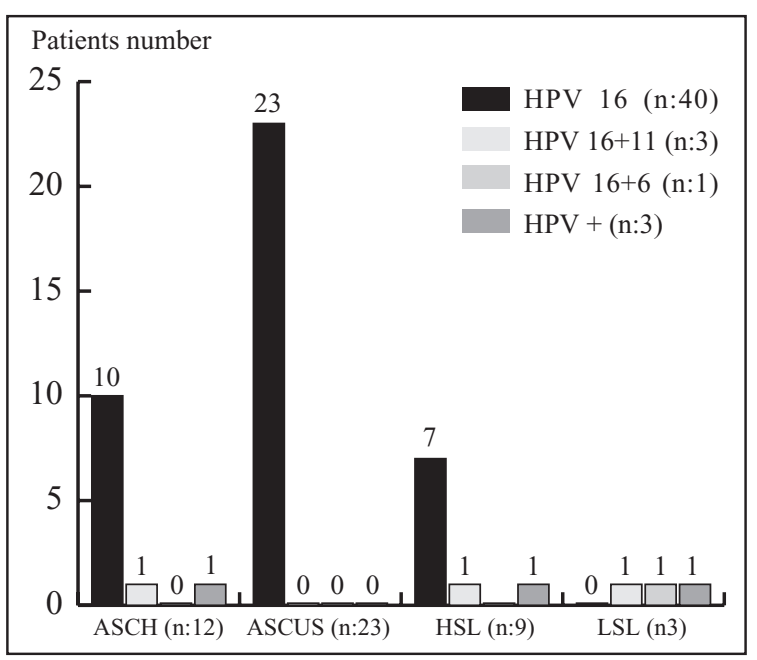

Figure 8: Positive of HPV types according to the data the pathology of the patients.

\section{DISCUSSION}

Human papillomavirus (HPV) is one of the most common sexually transmitted infections observed in sexually active adults and adolescents ${ }^{(11)}$. It is predicted that especially in developed countries, more than 50\% of sexually active females and males are infected with HPV in a period of their lives. The infection limits itself in $90 \%$ of HPV- infected women. However, it develops pre-cancerous or cancerous lesions as a result of ongoing changes within squamous epithelium for years in $10 \%$ of infected women ${ }^{(12)}$.

As serologic diagnosis methods are not effective for HPV detection and as they cannot be cultured yet; PCR method being one of the molecular based diagnosis methods is considered to be golden standard today $(13,14)$. In this study, real-time PCR method is used. The lesions that are developing in HPV typing is of importance. The oncogenic risk of HPV types makes them to be typed as low and high risk ${ }^{(15)}$. The most common HPV type in cervical cancer is HPV type 16 with the rate 
of 50-55\%; the second most common one is HPV type 18 with the rate of $10-15 \%(13,16)$. For that reason, this study focuses on HPV type 16 that is known as a highrisk HPV type and we think that this type is the primary reason of cancer and lesions which are highly important for treatment. Regarding the similar studies in Turkey, we can see that Yavuzer et al. (2009) revealed HPV DNA in 35 of 50 cases in their study conducted with nested PCR. Moreover, according to HPV typing in that study, it is detected that the most commonly encountered 3 HPV types are HPV 6/11 (42.9\%), HPV $16(22.9 \%)$ and HPV 18 (14.3\%) respectively(17). Altun et al. (2011) collected 460 cervical cytology from women aged between 20-68 years. In PCT test with MY09/11 and GP5+/6+ primers conducted for the detection of HPV DNA, they found HPV DNA to be positive in $24(5.2 \%)$ of 460 samples. In addition, they defined HPV positive samples; HPVpU-1M/pU-2R and primers; HPVpU-31B/pU-2R as high risk (HR) and low risk (LR) types respectively. They found that 14 (3\%) of 24 women with HPV DNA positive had positive HR HPV as mono or multiple infection and $10(2.2 \%)$ women had positive LR HPV ${ }^{(18)}$. Şahiner et al. (2012) included 356 cervical swab samples in their study conducted to investigate the presence of HPV DNA in cervical swap samples with two different methods. In that study, HPV DNA positivity rate is reported to be $30.9 \%$ with at least one of the methods. That study detected the frequency of HPV type 16 as $33.7 \%(19)$. Regarding other studies in the world, we can see that the data are different. In study conducted by Dunne et al (2007) in USA between 2003-2001, HPV frequency of 1921 women aged between 14-59 years was investigated with PGMY 09/11 primers and real time PCR method. They detected HPV positivity as $26.8 \%(20)$. Awadhi et al. (2011) examined 3011 cervical swab samples and they detected HPV DNA positivity rate to be $2.4 \%$ by means of real-time PCR method. In that study 21 different HPY genotypes were presented $^{(21)}$. On the other hand, in the present study, HPV DNA positivity is investigated in cervical swap samples of patients with suspected colposcopy by means of real time PCR method and the positivity is detected at the rate of $61.0 \%$. In addition, in this study it is detected that $52 \%$ of $47 \mathrm{HPV}$ positive people have HPV type $16 ; 4 \%$ have HPV type $16+11 ; 1 \%$ have HPV type $16+6$ and $4 \%$ have untyped HPV DNA. In cervical samples, the presence of HPV type 11 and
HPV type 6 indicates that non-malign HPV types can take place in cervical region.

When regarding studies that associate HPV prevalence and risk factors in cervical cancer, it is observed that the most common issues stated in risk factors are age, smoking, the use of OKS and RIA. The emphasis is on age and HPV prevalence mostly and it is reported that cervical neoplasia mostly occur at the end of the age of 20 s. While carcinoma in situ occurs at the age of $35 \mathrm{~s}$, invasive cancers are frequently seen between the ages of 55-60(22). Studies reveal that average diagnosis age of patients with cervical cancer is 51 . There are two peaks in lifetime with human papillomavirus. The first one occurs around the age of $30-40$ and the second one is at the age of 50-60 years. Studies conducted on many populations detect that HPV infections are associated with the age ${ }^{(23)}$. The infection decreases with increasing age and the reasons are explained with the low level of exposure to HPV, limited nature of infection and the resistance resulted from the repeated infection. In their study conducted to detect HPV DNA positivity of women diagnosed with normal and abnormal cervical smear, Batmaz et al. (2009) detected the positivity was at the lowest level (12.7\%) in the age group of 17-30 and the highest level $(52.4 \%)$ in the age group of $31-45$ and there is a fall (34.9\%) over the age of 45 . In that study, HPV positivity was found as $19.4 \%$ for women with normal cervical cytology who were in the age group of 17-30; $64.5 \%$ for those in the age group of $31-45$ and a fall $(16.1 \%)$ for those over the age of $45^{(22)}$. The present study is compatible with the literature. The first peak occurs between the age of 34-40 and the second one occurs between the age of 51-60 and a statistically significant difference is found in terms of HPV positivity between age groups $(\mathrm{p}<0.05)$. Moreover, in the present study it is detected that the highest HPV DNA positivity rate $80.0 \%$ ) is seen between the age of 21-40 years. It is detected that HPV positivity falls to $52.0 \%$ between the ages of $41-50$; however a second peak is observed with the increase to $83.3 \%$ between the age of 51-60. Statistical difference between age groups results from the fact that there is no HPV positive patient in the age group of 21-30 and over the age of 61 . It is seen that the results of studies conducted in Turkey to investigate the relationship between age and HPV are similar; however, there are some differences in the studies conducted abroad. This is 
mainly because of the fact that sexual mobility varies in age groups by sociocultural, economic structures and moral values of the society.

According to the studies of International Agency for Research on Cancer, to smoke in any period of time doubles the risk of cancer. The amount of smoking also increases risk rates. The fact that the high level lesion diagnosis rates of patients with HPV positive are 1.9-2.3 times more leads researchers to the conclusion that smoking is an important factor especially for persistence ${ }^{(24)}$. In addition, different results are found in studies conducted with oral contraceptives. While some studies found risk, some reported that there is no significant difference. Some of the recent publications with wide number of patients emphasize on the importance of the issue. IARCH studies also detected a relationship between the use of oral contraceptive (OKS) and cervical cancer (OR, 1.47; \%95 CI 1.02-2.12). It is detected that the use for less than 5 years does not increase the risk; however the use for between 5-9 years increases the risk 2.72 times more (95\% CI 1.36-5.46), the use for 10 years and more increases the risk 4.48 times more $(95 \% \mathrm{CI}$ 2.24-9.36)(24). In another study, it is reported that HPV DNA positivity and the use of OKS or smoking do not result in a statistically significant difference(22).

The studies conducted by the International Collaboration of Epidemiological Studies of Cervical Cancer (ICESCC) report that as the number of pregnancy increases, the risk of cervical cancer increases in direct proportion $^{(25)}$. In their study conducted to detect the presence of HPV in the pregnant, Channa et al. (2012) used 102 samples and $50 \%$ of them comprise the control group. According to that study, HPV DNA is detected in the pregnant at the rate of $19.6 \%$ and in non-the pregnant at the rate of $17.6 \%(26)$. In their study conducted to investigate the risk factors related to high risk HPV in women in the age group of 25-65 via PCR method, Rachel et al. (2012) detected the high risk HPV prevalence of 518 women to be $35.9 \%$. In that study 105 of 298 pregnant women had HPV positive and 42 women was detected to have high risk HPV. 81 of 2210 non pregnant women had HPV positivity and 35 women had high risk HPV ${ }^{(27)}$. In the present study, an increase in HPV positivity rate is detected with the increase in number of both child pregnancy. It is found that the positivity rate of those with $2-4$ children is $71.4 \%$ and those with $2-4$ pregnancy is $68.0 \%$. The positivity rate for those who have more than 4 pregnancy is $64.5 \%$. There is no statistically significant difference is found for HPV positivity by the number of children and pregnancy $(p>0.05)$. The data of this study is compatible with literature and a directly proportional relationship is found between pregnancy number and prevalence of HPV infection.

HPV infection in genital system may start with a lowgrade lesion and reach cancer ${ }^{28)}$. Ergünay et al. (2007) conducted their study on 35 patients (ASC-US of 14, ASC-H of 3, LSIL of 7, HSIL of 5, LSIL + suspected HSIL of 4, AGUS of 1 and atypical cells of 1 could not be diagnosed) and detected HPV DNA at the rate of $80 \%$ (28 patients). High risk HPV types $(16,18$, $31,33,45,56$ and 59) are detected in 22 of them $^{(29)}$. Batmaz et al. (2009), detected HPV positivity rates as $34.9 \%$ in ASCUS, as $66.6 \%$ in ASC-H and $31.2 \%$ in LSIL ${ }^{22}$. Castle et al. (2006) reported that HPV type 16 is a factor; ASCUS or LSIL lesions have risk to turn into CIN III or cancer within 2 years and this risk is 5 times more compared to other types except for HOV type $16^{(30)}$. Studies conducted by ICESCC (2006) reported HPV positivity rate as $35.4 \%$ for abnormal cytological results and this rate was $44.3 \%$ for normal cytological results. Moreover, in that study HPV positivity was reported to be $63 \%$ in ASCUS and $86 \%$ in ASC-H(25). In the present study, swap sample of patients are examined cytologically and HPV DNA is found to be positive in $12 / 60.0 \%$ ) of 20 ASC-H cases; in $23(63.8 \%)$ of 36 ASC-US cases; in $9(100 \%)$ of 9 HSIL cases and in 3 (25.0\%) of 12 LSIL cases. According to the data, a statistically significant difference is found for HPV positivity $(\mathrm{p}<0.05)$. This difference results from the fact that the whole group including HSIL cases was HPV positive.

In conclusion, HPV diagnosis which is regarded as a major factor in cervical cancer ethiology is of great importance today. Cervical cancer differs from other cancer types as it is "preventable" cancer type. For that reason, scanning, early diagnosis and treatment is important for HPV related infections. Within the light of all of the data obtained from this study, it is very important to guide and follow patients who are detected to have positivity by means of real-time PCR method in a certain algorithm. 


\section{REFERENCES}

1. Shope RE, Hurst EW. Infectious papillomatosis of rabits; with a note on the histopathology. J Exp Med 1933; 58: 607- 24.

2. Singer A, Ho L, Terry G, Kwie TS. Association of human papillomavirus with cervical cancer and precancer, In: A Mindel (eds), Genital Warts Human Papillomavirus Infection. Edward Arnold, London.1995; 105- 29.

3. Münger K, Baldwin A, Edwards KM et al. Mechanisms of human papillomavirus-induced oncogenesis. J Virol 2004; 78 (21): $11451-60$.

4. Howley PM. The molecular biology of papillomavirus transformation. Am J Pathol 1983; 113 (3): 414- 21.

5. Bosch FX, Lorincz A, Munoz N, et al. The causal relation between human papillomavirus and cervical cancer. J Clin Pathol 2002; 55: 244- 65.

6. Anna-Barbara Moscicki. Impact of HPV infection in adolescent populations. J Adoles Healt 37; 2005; 3- 9.

7. Hamont DW, Bekkers RLM, Massuger LFAG, Melchers WJG. Detection of management and follow-up of pre- malignen lesions and the role for human papillomavirus. Rev Med Virol 2008; 18: 117- 32 .

8. Özgül N. Türkiye'de serviks kanserinin durumu ve servikal kanser tarama çalışmaları. http://ukdk.org/pdf/kitap/30.pdf [Erisim Tarihi: 01.02.2010].

9. Lowy DR, Schiller JT. Prophylactic human papillomavirus vaccines. J Clin Invest 2006; 116: 1167- 73.

10. Solomon D, Davey D, Kurman R et al. Forum Group Members; Bethesda 2001 Workshop. The 2001 Bethesda System: terminology for reporting results of cervical cytology. JAMA 2002; 287: 2114- 9.

11. Yarkın F, Vardar MA. HPV immunolojisi ve natürel enfeksiyonlar. Türkiye Klinikleri J Gynecol Obst-Special Topics 2009; 2 (1): 43- 7.

12. Yazıcı F, Çelik Ç. HPV ve ekstragenital organ karsinomları. Türkiye Klinikleri J Gynecol Obst-Special Topics 2009; 2 (1): 29- 33 .

13. Maria TS, Paola L, Elvira B et al. Comparison of the digene hc2 assay and the roche amplicor Human papillomavirus (HPV) test for detection of high-risk hpv genotypes in cervical samples. J Clin Micro 2006; 44: 2141- 6.

14. Borysiewicz LK, Fiander A, Nimako M, et al. A recombinatinant vaccinia virus encoding human papillomavirus types 16 and 18, E6 and E7 proteins as immunotherapy for cervical cancer. Lancet 1996; 347: 1523- 7.

15. Erkmen E, Şimsek M, Sapmaz E ve ark. Bölgemizdeki serviks kanseri vakalarında HPV 16 ve 18 genomlarının PCR yöntemi ile araştırılması. Jinekol Onkol Derg 2002; 5: 75- 9.
16. Lorincz AT. Screening for cervical cancer: new alternatives and research. Salud Publica Mex 2003; 45 (3): 376- 87.

17. Yavuzer D, Karadayı N, Erdağı A, Salepçi T, Baloğlu H, Dabak R. Serviks kanseri ve prekanseröz lezyonlarında PCR ile HPV tiplemesi. Kartal Eğitim Araştırma Hastanesi Tıp Dergisi, 2009; 20(1): 1 - 6 .

18. Altun Z, Yarkın F, Vardar MA, Uğuz A. Çukurova Üniversitesi Tıp Fakültesi Hastanesine başvuran kadınlarda genital human papilomavirus enfeksiyon prevalansı. Turkiye Klinikleri J Med Sci 2011; 31(2): 307- 14

19. Şahiner F, Gümral R, Şener K, Yiğit N, Dede M, Yapar M, Kubar A. Servikal sürüntü örneklerinde iki farklı yöntemle HPV DNA varlığının araştırılması: MY09/11 Konsensus PCR ve Tipe özgül gerçek zamanlı PCR. Mikrobiol Bul 2012; 46(4): 624- 36.

20. Dunne EF, Unger ER; Sternberg M, et al. Prevalence of HPV infection among females in the United States. JAMA 2007; 297: $813-9$

21. Al-Awadhi R, Chehadeh W and Kapila K. Prevalence of Human Papillomavirus Among Women With Normal Cervical Cytology in Kuwait. Med J Virol 2011; 83: 453- 60.

22. Batmaz G, Çetin A, Dane C, Görgen H, Dane B. Normal ve anormal servikal smear saptanan kadınlarda HPV DNA pozitifliği. Türk Jinekolojik Onkoloji Dergisi 2009; 1: 10- 14

23. Baseman JG, Koutsky LA. The epidemiology of human papillomavirus infections. J Clin Virol 2005; 32: 16- 24.

24. International Agency for Research on Cancer. IARC Handbooks of Cancer Prevention. Cervix Cancer Screening. Lyon: IARC Press, 2005

25. International Collaboration of Epidemiological Studies of Cervical Cancer. Cervical carcinoma and reproductive factors: collaborative reanalysis of individual data on 16,563 women with cervical carcinoma and 33,542 women without cervical carcinoma from 25 epidemiological studies. Int J Cancer 2006; 119 (5): 1108- 24.

26. Schmeink CE, Melchers WJG, Hendriks JCM, et al. Human Papillomavirus Detection in Pregnant Women: A Prospective Matched Cohort Study. J of Women's Health 2012; 21(12): 1295- 01 .

27. Winer RL, Hughes JP, Feng Q, et al. Prevalence and Risk Factors for Oncogenic Human Papillomavirus Infections in High-Risk Mid-Adult Women. Sexually Transmitted Diseases 2012; 39 (11): 848- 56.

28. Köse F, Turan T. Servikal kanser tümörogenezi ve HPV. Türkiye Klinikleri J Gynecol Obst-Special Topics 2009; 2 (1): $13-8$.

29. Ergünay K, Misırlıglu M, Pınar F, Tuncer ZS, Tuncer S, Ustaçelebi S. Human papillomavirus DNA in cervical samples 
Phylogenetic analysis and prevalence of human papilloma virus (HPV) in women with several cervical pathologies

with cytological abnormalities and typing of the virus. Mikrobiyol Bul 2007; 41 (2): 219- 6.

30. Castle PE, Sadorra M, Garcia F, Holladay EB, Kornegay J.
Pilot Study of a Commercialized Human Papillomavirus (HPV) Genotyping Assay: Comparison of HPV Risk Group to Cytology and Histology. J Clin Micro 2006; 3915- 17. 